\title{
Identify the Essential Oils in Myrtus Communis L. Leaves
}

\author{
Muazaz A. AL-Hadeethi ${ }^{1}$, Aseel K. AL- Anbari ${ }^{2}$ and Salman A. AL-Dulimi ${ }^{3}$
}

\begin{abstract}
Essential oils compounds were identified in leaves of Myrtus communis during flowering stage by HPLC method, results of this study appearing six major compounds were, 1,8-cineole, $\alpha$ Pinene, $\alpha$-terpineol, Eucalyptol, Geranyl acetate, Limonene, and linalool. Concentration of these compounds a ranged between 18.28 $\mu \mathrm{g} / \mathrm{ml}$ in Geranyl acetate, and $45.22 \mu \mathrm{g} / \mathrm{ml}$ in Limonene, while $\alpha$ Pinene have been distinguished by highest concentration among six essential oils under study was $308 \mu \mathrm{g} / \mathrm{ml}$, this outcome data can be helpful as a significant medical and economic benefits.
\end{abstract}

Keywords - Myrtus communis L., myrtle, flowering stage, essential oil, chemical compounds.

\section{INTRODUCTION}

$M$ YRTUS communis L. is known as a medicinal plant to anti-hyperglycemic [1], antiseptic and anti-inflammatory activities [2] and [3]. It's considering a native plant of the Mediterranean and Asia such as Turkey, Iraq, Iran, and Syria. Over world there are more than one hundred warmth flourishing myrtle varieties, surely none has such regional cultural significance as Myrtus communis L.

Like all evergreen plants pleasant with aroma, it was also a counting a symbol of strong life force [4].

Different parts of the plant find various uses in food and cosmetic industries [5], such as leaves of Myrtle have been used as a substitute in beer [6], while the drinks prepared from myrtle berries became popular especially in Sardinia [7].

In additional, this species is regard significant aromatic plant because of high content of essential oil in different parts, such as leaf, flower, and fruit glands, due to the existence of rules and genetic fixed materials, the chemical has been possible differ by season [8].

The essential oils that called volatile oil mainly consists of Limonene, $\alpha$-pinene, $\beta$-pinene, $\beta$-myrcene and linalool .

These oils act as anti-bacterial properties, antifungal and antiviral, reducing the level of cholesterol, as well as antioxidant properties in cells it has been found [9] and [10].

Extracted essential oils from myrtle, have the effectiveness of a powerful antioxidant to own enzymatic mechanism and effectively to remove free radicals [11] and can be a reliable tool of chemotaxonomy methods to provide evidences data to diagnosis and separate taxa [12].

\footnotetext{
${ }^{1}$ Biology Dep., Education College For Pure Sciences - Ibn Al- Haitham, Baghdad University, Iraq.

${ }^{2}$ Biology Dep., Education College For Pure Sciences, Diyala University, Iraq.

${ }^{3}$ Ministry of Science and Technology, Baghdad, Iraq

*Corresponding Author E-mail: lubni_a75@yahoo.com.
}

Many references mention myrtle plant in ancient Egyptian medical texts as to remove mucus from the chest, a remedy for urinary disorders, pain, heartburn, swelling, stiffness of the limbs and cough also in Coptic medicine, the essential oil of myrtle was used in a prescription with fresh rue and a mineral for a number of skin disease [13].

Volatile oil of Myrtus communis have been used for several purposes, where the leaves are used to treat hypertension, hemorrhoids, common colds, cardiac disorders, urethral disorders, diarrhoea, internal diseases, rheumatic pain, edema in the extremities, lower blood glucose, pass kidney stones, as an appetite stimulant, hair restorer, wound healer and a haemostatic also the leaves by steam distillation is also commonly used to lower blood glucose [14], [15], [16], and [17].

Although it is known that both the berries and the leaves are used to macerate an aromatic liqueur called Mirto at the islands of Sardinia and Corsica [18].

The concentration of essential oils in myrtle leaf has been widely studied and data clearing that is differ according to regions and periods harvested [19], [5] and [20].

The evaluations of the fruit essential oil composition have also been reported [21], and [22].

Moreover, many phytochemical researches investigated at the same time the essential oil composition of leaves and fruits as well as the other parts of M. communis [23] and [24].

The purpose of this work is to determinate the quantitate of essential oils in $M$. communis leaves that may be useful for future studies as source of bioactive molecules..

\section{MATERIAL AND METHODS}

\subsection{Plants materials}

Fresh leaves of M. communis were collected in April 2015 at flowering period from plants that grown in different regions of Baghdad in the middle of Iraq.

\subsection{Essential Oils Extraction and Analysis}

Standard volatile oils data were in table 1 , and figure 1 . Method of extracting oil by hydro distillation [25] presented a range of pressurized hot water in either liquid or gas apparatus by which this process may be conducted as (steam) phases. Extracted components were passed and recovered on solid phase extraction cartridges SILICA mini column, the oil extracted by hexane: methylene chloride 50:50 (v/v) at different abundance. Oil was purified through filter paper was separate and diagnosis in a High Performance Liquid Chromatography - HPLC was injected samples. The concentration of each compounds were $50 \mu \mathrm{g} / \mathrm{ml}$. 
Column: $(3 \mu \mathrm{m})$, Particle size: $(50 \times 2 \mathrm{~mm}$ I.D), Solid phase: Silica column (Hexane: Methylene chloride 50:50 v I v), Mobile phase: content of: Solvent A-15\% formic acid in acetonitrile, Solvent B-45\% formic acid in acetonitrile, Starting from 15\% 45\% A B Deionized water 80:20, Detection UV set at $254 \mathrm{~nm}$.,Temp: $25 \mathrm{C}$, Flow rate: $1.2 \mathrm{ml} / \mathrm{min}$ Sample Injection volume: $20 \mu$, Modal: FLC-Shimadzu 10AVLC, Pump model: LC-10A Shimadzu, Monitored: VV-VIS 10A-SPD

We were calculated concentration of the oil in the sample according to the following equation:Conc. of Sample $\mu \mathrm{g} / \mathrm{ml}=$ (Area of sample) / (Area of standard) $\times$ conc.of standard $\times$ dilution factor.

TABLE I

Concentration Of Essential Oil In The MyrtLe Leaves.

\begin{tabular}{lc}
\hline \hline \multicolumn{1}{c}{ Essential oils } & $\begin{array}{c}\text { Concentration of the } \\
\text { Essential oils } \mu \mathrm{g} / \mathrm{ml} .\end{array}$ \\
\hline$\alpha$-pinene & 308 \\
Linalool cinole & 23.83 \\
$1-8 \quad 41.46$ \\
(Eucalyptol) & 45.22 \\
Limonene & 41.73 \\
$\alpha$-terpineol & 18.28 \\
Geranyl acetate & \\
\hline \hline
\end{tabular}

\section{RESUlTS AND DisCUSSION}

Large figures and tables may span both columns. Place Data shown indicate six important oils compounds found and their presence in a wide range of taxon under study these oils are (figure 1):

$\alpha$-Pinene is an organic compound of the terpene, It is found in the oils of many species like as coniferous trees, notably the pines, it is also found in the essential oil of rosemary and present in some oils such as eucalyptus oil and orange peel oil [26] . $\alpha$-Pinene is an anti-inflammatory via PGE1 and seems to be a broad-spectrum antibiotic [27]. It exhibits activity as an acetylcholinesterase inhibitor, aiding memory [28]. Concentration of $\alpha$-Pinene in the myrtle leave was $308 \mu \mathrm{g} / \mathrm{ml}$.

The other oil in the myrtle leaves is linalool, it's likewise a normally occurring terpene alcohol chemical in numerous blossoms and spice plants, The other names to linalool ( $\beta$ linalool, linalyl alcohol, linaloyl oxide, $p$-linalool and alloocimenol) [29]. Linalool is utilized as perfume part in 60$80 \%$ of perfumed cleaning items and cleaning specialists including cleansers, shampoos, and cream body [30]. Additionally as a substance moderate of vitamin E [31]. The concentration of linalool in the myrtle leaves $23.83 \mu \mathrm{g} / \mathrm{ml}$.

Eucalyptol or 1,8-cineole includes up to $90 \%$ of the vital oil of a few types of the nonspecific item Eucalyptus oil, Eucalyptol is an ingredient in many trademark of mouthwash and cough drugs, as well as use in the body powder [32]. Eucalyptol is used also as an insecticide and insect repellent [33], and [34]. The Concentration of Eucalyptol in the myrtle leaves arrived to $41.46 \mu \mathrm{g} / \mathrm{ml}$.

Limonene is a colourless liquid hydrocarbon classified as a cyclic terpene, is common in cosmetic products, as the main odor constituent of citrus, limonene is used in food industrialization and some drugs like as a flavouring to disappear the bitter taste of alkaloids and as an aroma in perfumery, aftershave lotions, bath products and other such products that include perfume, it is also used as botanical insecticide [35]. In natural and alternative medicine, $d-$ limonene is marketed to relieve gastroesophageal reflux disease and heartburn [36]. Limonene is an adenosine agonist which may explain its antistress and calmative properties [37]. Concentration of this compound in myrtle leaves was arrived to $45.22 \mu \mathrm{g} / \mathrm{ml}$.

The other oil Terpineol is a naturally occurring monoterpene alcohol that has been isolated from a variety of sources such as cajuput oil, pines oil, and petitgrain oil [38]. Terpineol has a nice odor similar to lilac and is a common agent in perfumes, cosmetics, and flavors. $\alpha$-Terpineol is one of the two most abundant taste constituents of lapsang souchong tea (a variety of souchong tea with a smoky flavor) the $\alpha$-terpineol construct in the pine fume used to dry the tea [38]. The Concentration of terpineol in myrtle leaves was arrived to $41.73 \mu \mathrm{g} / \mathrm{ml}$.

The sixth oil was Geranyl acetate is a natural organic compound that is classified as a monoterpene, Geranyl acetate is used primarily as a component of perfumes for creams body and soaps and as a flavoring ingredient. It is used particularly in rose, lavender and geranium formulations where a sweet fruity or citrus aroma is desired [39]. The concentration of this compound was $18.28 \mu \mathrm{g} / \mathrm{ml}$ in the leaves of myrtle.

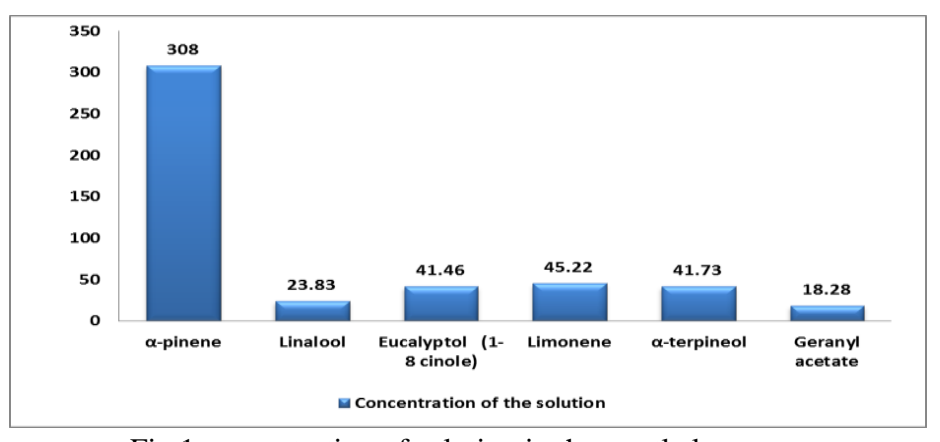

Fig 1 concentration of solution in the myrtle leaves

\section{ACKNOWLEDGMENT}

We would like to thank Professor Dr. Fadhil M. Abid, from Biotechnology Center of the Ministry of Science and Technology in Baghdad, Iraq for helping to analyses the essential oil in the plant leaves.

\section{REFERENCES}

[1] M. Elfellah, M. Akhter, and M. Khan, "Anti-hyperglycaemic effect of an extract of Myrtus communis in streptozotocin induced diabetes in mice". Journal of Ethnopharmacology, vol. 11, pp. 275-281, 1984. http://dx.doi.org/10.1016/0378-8741(84)90073-4

[2] A. M. Diaz, and A.Abeger, "Myrtus communis: composicion quimica y actividad biologica de sus extractos. Una revision". Fitoterapia, vol. 58, pp. 167-174, 1987.

[3] M. K.Al-Hindawi, I. H.Al-Deen, M. H. Nabi, and M. A. Ismail, "Antiinflammatory activity of some Iraqi plants using intact rats". Journal of Ethnopharmacology, vol.26, pp. 163-168, 1989. http://dx.doi.org/10.1016/0378-8741(89)90063-9

[4] M. Heilmeyer, Myrtle, in Ancient Herbs, Getty Publications. 2007. 
[5] J. C.Chalchat, R. F. Garry, and A. Michet, "Essential oils of Myrtle (Myrtus communis L.) of the Miterranean littoral". Journal of Essential Oil Research, vol. 10, pp. 613-617.1998.

[6] S. H. Buhner, "Sacred and herbal healing beers."Boulder, CO: Brewer Publications. 1998.

[7] F. Nuvoli, and D. Spanu, "Analisi e prospettive economiche dell'utilizzazionze industriale del mirto. Rivista Italiana" EPPOS, vol. 12, pp. 231-236.1996.

[8] O.Fadi, R. Abdulkader, A. Samir, and C. Eyad . "The cytotoxic effect of essential oils C.aurantium peels on humen colorectal carcinoma cell line(LIMI1863).” JMBFS, 1(6)1476-1487. 2012.

[9] M. Blumenthal,"Bitter orange peel and synephrine." in American botanical council. 2002. (2).

[10] P. Singh, R. Shukla, B. Prakash, A. Kumar, S. Singh, P. K. Mishra, and N.K. Dubey. "chemical profile, antifungal, antiaflatoxigenic and antioxidant activity of Citrus Maxima Burm. and Citrus Sinensis(L.) Osbeck essential oils and their syclic monoterpene, DL-Limonen". $J$. Chem. Toxicol. vol. 48, pp. 1734-1740. 2010. http://dx.doi.org/10.1016/j.fct.2010.04.001

[11] R.Pérez-Rosés, E. Risco, R.Vila, P. Penalver, and S.Cañigueral.). "Antioxidant activity of eleven essential oils by two different In Vitro Assays". 39th International Symposium Of Essential Oils. Germany.2008, 39- 47.

[12] A. K. AL-anbari1, T. A.alkhesraji ,A al-Mashhadani, and H Aljewari. "Determination of some chemical compounds in Citrus species in Iraq." International Journal of Advanced Research Vol. 1( 7), pp. 555-562 555, 2013, ISSN NO 2320-5407 http:// www.journalijar.com.

[13] L. Manniche, "An Ancient Egyptian Herbal. Austin," University of Texas Press. 1999.

[14] E. Yeşilada, G. Honda, E. Sezik, M. Tabata, T. Fujita, T. Tanaka, Y. Takeda, and Y.Takaishi, "Traditional Medicine in Turkey V. Folk Medicine in the Inner Taurus Mountains." Journal of Ethnopharmacology, vol. 46, pp. 133-152. 1995. http://dx.doi.org/10.1016/0378-8741(95)01241-5

[15] T. Baytop,'Therapy with Medicinal Plantsin Turkey. Past and Present" [in Turkish], İstanbul, Nobel Publications, 1999.

[16] F. Ertuğ, . "Medicinal plants used in the folk medicine of Bodrum area". K.H.C. Başer and N. Kırımer (Eds.) - 14. Bitkisel İlaç Hammaddesi Toplantısı, Bildiriler, 29-31 Mayıs 2002, Eskișehir, ebook: $2004 \mathrm{http} / / /$ documents.anadolu.edu.tr/bihat.

[17] E. Tuzlaci, "Sifa Niyetine". The Herbal Medicinal Plants of Turkey [in Turkish], İstanbul (Alfa Yayınları, No. 1702). 2006.

[18] P.M. Guarrera, G. Salerno, and G. Caneva, "Food, Flavoring and Feed Plant Traditions in the Tyrrhenian Sector of Basilicata", Italy. Journal of Ethnobiology and Ethnomedicine, vol. 2, pp. 37. 2006. http://dx.doi.org/10.1186/1746-4269-2-37

[19] P. Bradesi, F. Tomi, J. Casanova, J. Costa, and A. F. Bernardini," Chemical composition of myrtle leaf essential oil from Corsica (France)". Journal of Essential Oil Research, vol.9, pp. 283-288.1997.

[20] C. Gardeli, V. Papageorgiou, A. Mallouchos, K. Theodosis, and M. Komaitis, "Essential oil composition of Pistacia lentiscus L. and Myrtus communis L.: Evaluation of antioxidant capacity of methanolic extracts", Food Chemistry, vol. 107, pp. 1120-1130, 2008. http://dx.doi.org/10.1016/j.foodchem.2007.09.036

[21] G. Mazza, "Gas cromatographic-mass spectrometric investigation of the volatile components of myrtle berries (Myrtus communis L.)". Journal of Chromatography, vol. 264, pp. 304-311. 1983. http://dx.doi.org/10.1016/S0021-9673(01)95036-8

[22] M.Mulas, D. Spano, S. Biscaro, and L.Parpinello, "Parametri di qualità dei frutti di mirto (Myrtus communis L.) destinati all'industria dei liquor". Industrie delle Bevande, vol. 29, pp. 494-498. 2000.

[23] C. I. G.Tuberoso, A. Barra, A. Angioni, E. Sarritzu, and F. M. Pirisi, "Chemical composition of volatiles in Sardinian myrtle (Myrtus communis L.) alcoholic extracts and essential oils." Journal of Agriculture and Food Chemistry, vol. 54, pp.1420-1426. 2006. http://dx.doi.org/10.1021/jf052425g

[24] W.Aidi-Wannes, B. Mhamdi, and B. Marzouk, "Essential oil composition of two Myrtus communis L. varieties grown in North Tunisia." Italian Journal of Biochemistry, vol. 56, pp.180-186. 2007.

[25] S. Rovio, K. Hartonen , Y. Holem, R. Hiltunen, and M. Riek. Flavourfragr. J.vol. 14, pp. 399. 1999.

[26] H. David, "PDR for Herbal Medicine." Medical Economics Company, fourth edition. 2000. pp. 1109. ISBN: 1-56363-361-2.
[27] L . Nissen, A. Zatta,I. Stefanini, S. Grandi, B. Sgorbati, and B. Biavati, "Characterization and antimicrobial activity of essential oils of industrial hemp varieties (Cannabis sativa L.). "Fitoterapia, vol. 81, pp. 413-419. 2010. http://dx.doi.org/10.1016/j.fitote.2009.11.010

[28] E. B. Russo, "Taming THC: potential cannabis synergy and phytocannabinoid-terpenoid entourage effects." British Journal of Pharmacology, vol. 163 (7), pp. 1344-1364. 2011. http://dx.doi.org/10.1111/j.1476-5381.2011.01238.x

[29] H. Casabianca, J. B. Graff, V. Faugier, F. Fleig, and C. Grenier, "Enantiomeric distribution studies of linalool and linalyl acetate. A powerful tool for authenticity control of essential oils." HRC J High Res Chrom, vol. 21, pp. 107-112.1998

[30] A. Pengelly, "The Constituents of Medicinal Plants." 2nd Ed. CABI Publishing, U.S.A. and UK. 2004.

[31] E. Lewinshon, F. Schalechet, J. Wilkinson, K. Matsui, Y. Tadmor, K. Nam, , O. Amar, E. Lastochkin, O. Larkov, U. Ravid, W. Hiatt, S. Gepstein, and E. Pichersky, "Enhanced levels of the aroma and flavor compound S-linalool by metabolic engineering of the terpenoid pathway in tomato fruits." Plant Physiol , vol. 127, pp. 1256-1265, 2001. http://dx.doi.org/10.1104/pp.010293

[32] F. P. Schiestl, and , D. W.Roubik, "Odor Compound Detection in Male Euglossine Bees." Journal of Chemical Ecology, vol. 29 (1), pp. 253-257. 2004 http://dx.doi.org/10.1023/A:1021932131526

[33] J. A. Klocke, M. V. Darlington, and M. F. Balandrin, "8-Cineole (Eucalyptol) a Mosquito Feeding and Ovipositional Repellent from Volatile Oil of Hemizonia fitchii (Asteraceae)." Journal of Chemical Ecology, vol. 13 (12), pp. 2131.1987.

[34] V. Sfara, E. N. Zerba, and R. A. Alzogaray, "Fumigant Insecticidal Activity and Repellent Effect of Five Essential Oils and Seven Monoterpenes on First-Instar Nymphs of Rhodnius prolixus." Journal of Medical Entomology, vol.46 (3), pp. 511-515. 2009. http://dx.doi.org/10.1603/033.046.0315

[35] M. Matura, A. Goossens, O. Bordalo, B. Garcia-Bravo, K. Magnusson, K . Wrangsjö, and A. Karlberg, "Oxidized citrus oil (Rlimonene): A frequent skin sensitizer in Europe." Journal of the American Academy of Dermatology, vol. 47 (5), pp. 709-14. 2002. http://dx.doi.org/10.1067/mjd.2002.124817

[36] J. Sun," d-Limonene: safety and clinical applications. Alternative medicine review", journal of clinical therapeutic, vol.12 (3), pp. 25964. 2007.

[37] H. M. Park, "Limonene, a natural cyclic terpene, is an agonistic ligand for adenosine A (2A) receptors." Biochem Biophys Res Commun, pp. 345-348, 2011 http://dx.doi.org/10.1016/j.bbrc.2010.11.121

[38] Y.Shan-Shan, G. Wen-Fei, L. Yi, and J. Yuan-Xun, "Flavor Characteristics of Lapsang Souchong and Smoked Lapsang Souchong, a Special Chinese Black Tea with Pine Smoking Process." Journal of Agricultural and Food Chemistry, vol. 53 (22), pp. 8688-8693. 2005. http://dx.doi.org/10.1021/jf058059i

[39] P. A. Claon, and C. C. Akoh, "Enzymatic Synthesis of Geraniol and Citronellol Esters by Direct Esterification in n-Hexane," Biotechnol. Lett., vol. 15, pp. 1211-1216. 1993. http://dx.doi.org/10.1007/BF00130299 